\title{
Attitude of farmers towards Non-Governmental Extension Organisations in Oyo-State, Nigeria
}

\author{
Tijani S.A and Mudashir H.B. \\ Department of Agricultural Extension and Rural Development, \\ Faculty of Agriculture and Forestry, University of Ibadan, Ibadan. Oyo State, Nigeria. \\ GSM: 08051370802, tsarafat@yahoo.com
}

\begin{abstract}
The study examined the attitude of farmers towards non-governmental extension organisations (NGEOs) in Oyo State. Multi-stage sampling procedure was used to choose 160 respondents. Data were collected through interview schedule and analyzed using both descriptive and inferential statistics at $p=0.05$. More than one-third of the respondents were in the age bracket of 41-50years, majority were males (67.5\%), 76.9\% had ten years of formal education and $81.9 \%$ were married. Only $28.8 \%$ cultivated between 2.43-4.05hectares, $23.7 \%$ had more than 20years of farming experience and $65.0 \%$ grew cash crop. Majority (86.3\%) of the respondents were aware of NGEOs through radio and FADU was ranked $1^{\text {st }}$ followed by Leventis as the most prominent NGEOs. Greater percentage (93.7\%) was willing to pay for the services of the organizations. However, $82.5 \%$ could only afford between N1,000.00-N10,000.00/month. Prohibitive cost of services provided (mean = $0.719)$ was the major limiting factors to respondents' willingness to access services of NGEOs. Notwithstanding, 57.5\% had favourable attitude towards NGEOs. There was significant relationship between years of formal education $(r=0.346)$, years of farming experience $(r=0.187)$, marital status $\left(X^{2}=25.47\right)$, primary occupation $\left(X^{2}=10.016\right)$ and attitude towards NGEOs. Also, type of crops grown $\left(X^{2}=4.32\right)$, willingness to pay $\left(X^{2}=9.525\right)$, number of hectares under cultivation $(r=0.171)$, source of information $(r=0.519)$ and constraints to using NGOE services $(r=0.428)$ had significant relationships with respondents' attitude towards NGEOs. Synergies and collaboration between governmental and NGEOs become imperative for efficient and effective delivery of extension services.
\end{abstract}

Key words: Non-governmental extension organization, attitude of farmers

\section{Introduction}

Extension service is particularly important to farmers in order to increase their agricultural production by transferring information aimed at increasing knowledge, attitude and skills of the farmers. More so, in many developing countries, agricultural development is hinged on extension services by helping farmers to identify, analyze and link with research on their production problems. They also create awareness on opportunities for improvement of farm yields leading to increased income and better standard of living (Van den ban and Hawkins, 1998; Balantyne and Bokre, 2003)

In many developing countries among which Nigeria is one, extension services are being provided by government with the advantage of national coverage of all the farmers and guaranteed minimum funding that address common issues. Meanwhile, due to the need to meet diverse range of services including information on markets, rural industries and other income opportunities private extension is being advocated (Kidd, Lamers, Ficarelli, Hoffmann, 2000; Rivera, 2001). Private extension is simply the provision of a service or advice by a private firm in exchange for a fee; the terms and conditions of the transaction are negotiated. 
The degree to which this can be done in practice depends on the willingness to pay for such services, especially in a situation where agricultural information is commonly seen as a public good because of its low excludability and low subtractability (Alex et al, 2002). Agricultural information provided as a private good does not necessarily require the existence of a highly commercialised agricultural system. Under private extension system, extension professionals are capable of training and motivating farmers for best use of resources available to them.

The attainment of the Agricultural Transformation Agenda (ATA) policies of the Federal Government of Nigeria which is aimed at restructuring fertilizer procurement and distribution, marketing institutions, financial value chains and agricultural investment framework can be enhanced when non-governmental extension organization (NGEOs) are factored into the whole process. In addition, these private extension organisations can also help to adapt/promote the transformation policies to suit the needs of farmers.

Meanwhile, public extension services in Nigeria were noted for adequacy and effectiveness when the programmes were sponsored by the World Bank. Inadequacies occurred following the withdrawal of the assistance of the World Bank and this make the programmes to be criticised for being inefficient and ineffective; lacking clear objectives, motivation and incentives; poorly managed and not accountable to clients; low coverage due to shortage of staff, lacking relevant technologies and financial sustainability.

To develop agriculture and farmers which is the main aim of Agricultural Transformation Agenda, NGEOs must come into play. In Nigeria however, NGEOs have started complementing government extension services. Majority of these NGEOs are small and horizontally structured with short lines of communication and are therefore capable of responding flexibly and rapidly to clients' needs and to changing circumstances. They are also characterized by a work ethic conducive to generating sustainable processes and impacts. NGEOs' are concerned with the rural poor, and this means that they often maintain a field presence in remote locations, where it is difficult to keep government staff in post. Some of these NGEOs in Oyo state are; Farmers Development Union (FADU), Leventis Foundation, British American Tobacco (BAT), Food Basket Foundation International (FBFI), Pan African Society for Rural Development and Profession (PASRUDEP), West Agro Input Dealers Association (WAIDA) to mention a few. Farmers' attitude towards the services being provided with consequent readiness to pay need to be determined in order to promote the dissemination of ideas and information.

The specific objectives were to:

- determine the level of awareness and the source(s) of information of the respondents on NGEOs;

- know if the farmers are ready and willingly to pay for the service of NGEOs;

- determine the perception of farmers towards NGEOs and the constraint(s) limiting the use of NGEOs by the respondents

- investigate the relationship between the selected demographic characteristics of respondents, level of awareness, source of information, willingness to pay, constraints to the use of NGEOs and the attitude of respondents toward NGEOs.

\section{Methodology}

The study was carried out in Oyo state, which is an inland state in south-western Nigeria with its capital at lbadan. The state covers, approximately, an area of $28,454 \mathrm{~km}^{2}$. Oyo state has a population of 5,591,589 people (National Population Census, 2006), and agriculture is the main occupation of the people

The population of the study consisted of all crop farmers across the selected local governments areas (LGAs) of the state. Multi-stage sampling method was employed. Four 
LGAs were purposively selected from the thirty-three LGAs of the state based on the presence of NGEOs. Simple random sampling was used to select four wards in each LGA. A community was randomly selected from each ward and the last stage involved random selection of ten farmers in each community to give a total of 160 respondents. Interview schedule was used to collect data.

Awareness of NGEOs was measured as: aware $=1$, not aware $=0$ and the mean were obtained through the division of frequency of each organization by total number of respondents; then ranking was done from highest mean to the lowest. Willingness to pay was done through yes $=1$ and no=0. Attitude towards NGEOs was measured using a fivepoint Likert type scale of strongly agree, agree, undecided, disagree and strongly disagree with the score of 5, 4, 3, 2 and 1 respectively for positive statements and reverse order of the scores for negative statement. The mean was obtained and used to categorise respondents' attitude to favourable (mean and above) and unfavourable (below mean).

\section{Results and Discussion}

\section{Personal characteristics of respondents}

Table 1 reveals that $9.4 \%$ were below 31 years, $22.4 \%$ fell between $31-40$ years, the majority (37.5\%) fell between $41-50$ years and $30.6 \%$ were above 50 years of age. This implies that the respondents were both young and middle-aged farmers who were active, highly ambitious and would therefore need extension services to reach them in order to boost their production. It however contradicts the position of Angba (2003) that most of the young people have migrated from the rural areas. Results further show that majority of the farmers were married (81.9\%). One could infer that they engaged in agriculture in order to cater for family needs, which is in line with Akinbile et al. (2008) that marriage confers responsibility. Majority of the farmers were males (67.5\%). This is in accordance with the findings of Torimiro and Oluborode (2006) that farming in the rural areas is dominated by male. The result also coincides with the commonly held view that agriculture is mainly for males because of the drudgery associated with it as reported by Agbebaku (2004). However, a sizeable proportion of sampled farmers were females (32.5\%), who can therefore be reached by extension agents so as to encourage female farmers to engage more in agricultural activities. Majority $(76.9 \%)$ had only primary education, it implies that they may find it difficult to understand extension innovations and thereby making adoption impossible. Ojo (2005) noted that the lower the level of education of an individual, the lesser the knowledge they can acquire. Majority $(63.11 \%)$ cultivated $\leq 2.02$ hectars of land, which may be attributed to the method of land acquisition and the problem of land fragmentation as also noted by Oladele et al (2009). This supports Ogunsumi and Ewuola (2005) that most of agricultural farms in southwest Nigeria are on small scale varying between $0.1-5 \mathrm{ha}$. A sizable number $(41.3 \%)$ of the farmers had $\leq 10$ years of farming experience. Furthermore, $65.0 \%$ grew cash crops as opposed to $35.0 \%$ that grew arable crops. The farmers could therefore be categorised as commercial farmers (who may be in need of supplemental extension services), while those that grew arable crops may be considered as subsistence farmers. 
Table 1: Distribution of respondents' personal characteristics

\begin{tabular}{|c|c|}
\hline Variables & Percentage $(n=160)$ \\
\hline \multicolumn{2}{|l|}{ Age } \\
\hline$\leq 30$ & 9.4 \\
\hline $31-40$ & 22.4 \\
\hline $41-50$ & 37.5 \\
\hline$\geq 51$ & 30.6 \\
\hline \multicolumn{2}{|l|}{ Sex } \\
\hline Male & 67.5 \\
\hline Female & 32.5 \\
\hline Total & 100 \\
\hline \multicolumn{2}{|l|}{ Marital status } \\
\hline Single & 8.1 \\
\hline Married & 81.9 \\
\hline Widow & 5.0 \\
\hline Widower & 1.3 \\
\hline Divorced & 3.8 \\
\hline \multicolumn{2}{|c|}{ Years of formal education } \\
\hline $0-10$ & 76.9 \\
\hline $11-20$ & 20.6 \\
\hline$\geq 21$ & 2.5 \\
\hline Total & 100 \\
\hline \multicolumn{2}{|l|}{ No of hectares } \\
\hline $0-2.02$ & 63.1 \\
\hline $2.43-4.05$ & 28.8 \\
\hline$\geq 4.05$ & 8.1 \\
\hline Total & 100 \\
\hline \multicolumn{2}{|c|}{ Farming experience } \\
\hline $0-10$ & 41.3 \\
\hline $11-20$ & 35.0 \\
\hline 21 and above & 23.7 \\
\hline Total & 100 \\
\hline \multicolumn{2}{|l|}{ Crop grown } \\
\hline Cash crop & 65.0 \\
\hline Arable crop & 35.0 \\
\hline Total & 100 \\
\hline
\end{tabular}

Field Survey, 2012

\section{Awareness of non-governmental extension organisations}

The result shows that $87.5 \%$ of the farmers were aware of NGEOs, and since most are aware, there is possibility for them to make use of the recommended farm practices suggested by the NGEOs, which is also the view of Akinbile and Odebode (2007).

The ranking of the different NGEOs (Table 2) according to their awareness level reveals that Farmers Development Union (FADU) ranked $1^{\text {st }}$ with mean $=0.86$, which follows that it was the most famous NGEOs among the listed organisations. FADU is well known by the farmers due to the general agricultural services rendered by it and probably because its 
presence cuts across the states within Nigeria. LEVENTIS, which is also known for rendering a series of assistance to farmers was ranked $2^{\text {nd }}$ with mean $=0.69$ followed by NTC (mean= 0.6582). NTC is popular among the tobacco farmers because it deals with tobacco. Food Basket Foundation International (FBFI) came $4^{\text {th }}$ with $63.1 \%$. FBFI was set up to assist low income families, to achieve food security on a sustainable basis especially for members of the vulnerable groups. Majority of these farmers can be categorised among low income families which means that FBFI might have been reaching them.

Nevertheless, British American Tobacco (BAT) and Sarumi Agro Chemical (SARO) were both ranked $5^{\text {th }}$ with $60.0 \%$. BAT is known for regulation of the tobacco sector, building a potential for regional export of tobacco and establish an independent foundation to address rural socio economic development. These mandates make some of the farmers especially the tobacco farmers to be aware of the organisation in order to improve their productivity. SARO deals with the distribution of Agro chemicals to improve agricultural production. Less prominent organizations among the respondents are West Agro Input Dealers Association (WAIDA) which is another organisation that deals with the distribution of agro chemical to the farmers, Council of Women Association of Nigeria (COWAN) that is an organisation set up in order to empower women and Pan African Society for Rural Development and Profession (PASRUDEP). It can be said that the farmers were more aware and make use of organizations that are applicable to their production because they all have different mandates.

Table 2: Farmers' awareness of non-governmental extension organisations

\begin{tabular}{llll}
\hline NG extension organisations & $\begin{array}{l}\text { Percentage } \\
(\mathbf{N}=\mathbf{1 6 0})\end{array}$ & Mean & Rank \\
\hline BAT & 60.0 & 0.60 & $5^{\text {th }}$ \\
NTC & 65.0 & 0.65 & $3^{\text {rd }}$ \\
FBFI & 63.1 & 0.63 & $4^{\text {th }}$ \\
FADU & 86.3 & 0.87 & $1^{\text {st }}$ \\
JDPC & 46.3 & 0.46 & $9^{\text {rd }}$ \\
WAIDA & 56.3 & 0.56 & $7^{\text {th }}$ \\
SARO & 60.0 & 0.60 & $5^{\text {th }}$ \\
COWAN & 51.9 & 0.51 & $8^{\text {th }}$ \\
PASRUDEP & 43.8 & 0.44 & $10^{\text {th }}$ \\
LEVENTIS & 69.4 & 0.69 & $2^{\text {nd }}$ \\
\hline
\end{tabular}

Source: Field survey, 2012

\section{Sources of information on NGEOs available to respondents}

Adewoye et al (2003) reflected that the more the variety of channels and methods used in introducing new ideas, the greater the chance of accepting new innovations by farmers. The findings in Table 3 show that out of the different sources of information available to the farmers on NGEOs, radio was the primal source and thus ranked $1^{\text {st }}$ with the mean score of 0.71 . This is admissible because majority of the respondents listen to radio almost every day, particularly in the evenings after their days' work. Likewise, Ajayi (2003) found the use of radio as the most popular source of information in southwest Nigeria, where the study was carried out. Family and friends was ranked $2^{\text {nd }}$ which goes in line with the 'Teach One Teach All model of information dissemination. Association was ranked $3^{\text {rd }}$ while postal service ranked last $\left(8^{\text {th }}\right)$, consequent on the fact that majority of the farmers only had primary education which may be a disadvantage, coupled with them being in rural areas that lack postal facilities. 
Table 3: Information sources on NGEOs and their ranks

\begin{tabular}{llll}
\hline Source & Means & S.D & Rank \\
\hline Television & 0.5660 & 0.49719 & $5^{\text {th }}$ \\
Radio & 0.7107 & 0.45487 & $1^{\text {st }}$ \\
Newspaper & 0.6062 & 0.49011 & $4^{\text {th }}$ \\
Extension agent & 0.5312 & 0.50059 & $6^{\text {th }}$ \\
Family and friend & 0.7062 & 0.45691 & $2^{\text {nd }}$ \\
Association & 0.6938 & 0.46238 & $3^{\text {rd }}$ \\
Seminar & 0.4125 & 0.49383 & $7^{\text {th }}$ \\
Postal & 0.2688 & 0.44470 & $8^{\text {th }}$ \\
\hline
\end{tabular}

Source: Field survey, 2012

\section{Willingness to pay and amount willing to pay for extension services}

The free services provided by public extension have, one way or the other led to the inefficiency of the practice. NGEOs which are based on the principle of "pay for service" are now in existence. Farmers' opinion towards NGEOs was investigated and the result reveals majority $(90.6 \%)$ were willing to pay for extension services. Commercial farmers may be more willing to pay because of the benefit they tend to derive from the services of these private extension agents. This corroborated Ogunlade et al (2009), that there is a strong and positive correlation between farm size, scale of operation and willingness to contribute to sustainable funding.

However, 9.4\% were not willing to pay. In terms of amount willing to pay, $82.5 \%$ were willing to pay between $1000-10,000$ naira/month while only few $(11.2 \%)$ were willing to pay more than 10,000 naira/month. This may be due to the fact that they were not operating on the same scale of production; some of them were subsistence farmers who only produce for home consumption, while others may be producing at commercial level and will not only need extension services but at the same time ready to commit a fee in an attempt to increase their productivity.

Table 4: Distribution of respondents by willingness to pay for extension services

\begin{tabular}{ll}
\hline Variable & Percentage $(\mathbf{n = 1 6 0})$ \\
\hline Willing to pay & 90.6 \\
Unwilling to pay & 9.4 \\
Total & $\mathbf{1 0 0}$
\end{tabular}

Source: Field Survey, 2012.

\section{Attitude towards non-governmental extension organizations}

Table 5 shows that $57.5 \%$ of the respondents had favourable attitude while $42.5 \%$ had unfavourable attitude towards NGEOs services and the mean score was 73.0. This reasonably favourable attitude towards NGEOs services exhibited by the farmers could be consequent upon the fact that most of the farmers, especially those who produced in commercial quantities and were financially buoyant to adopt any innovation brought to them, had the impression that whatever resources they spent on any innovation or information will be eventually recovered in manifolds. 
They are thus more likely to be always favourably disposed towards NGEOs relative to small scale farmers, who produce for household consumption that may not be able to afford new innovations.

Table 5: Categorization of respondents' attitude towards NGEOs

\begin{tabular}{lcccc}
\hline Attitude & Frequency & Percentage & Mean score & Standard deviation \\
\hline Favourable (73-93) & 92 & 57.5 & 73.0 & 8.5 \\
Unfavourable(43-72) & 68 & 42.5 & & \\
\hline
\end{tabular}

Source: Field survey, 2012

\section{Constraints to the use of non-governmental extension services}

Table 6 shows the constraints faced by the respondents in using NGEO services. One of the advantages of public extension is that its services are rendered free of charge to its beneficiaries, unlike those of NGEOs services which are administered at a cost. It is therefore not a surprise that the farmers indicated that the primal bane to the use of nongovernmental extension services was its expensiveness (rank $=1^{\text {st }}$, mean $=0.72$ ). It is widely known that government's attitude towards agriculture nose-dived after the advent of crude oil in Nigeria. It is not strange that such scenario (poor government policy) will also apply to the practice of non-governmental extension ( $r a n k=3^{\text {rd }}$, mean $=0.70$ ). Unavailability of trained extension personnel which otherwise is literally seen as a major barrier to the smooth operation of extension services in the country ranked only $6^{\text {th }}$ (mean $=0.58$ ), indicating that it was not really a serious concern to the farmers.

Table 6: Ranking of constraints to the use of NGEO services by respondents

\begin{tabular}{llll}
\hline Constraints & Means & SD & Rank \\
\hline Too expensive & 0.7188 & 0.45102 & $1^{\text {st }}$ \\
Accessibility & 0.6750 & 0.46985 & $5^{\text {th }}$ \\
Government policy & 0.7000 & 0.45970 & $3^{\text {rd }}$ \\
Time consuming & 0.7063 & 0.45691 & $2^{\text {nd }}$ \\
Unavailability of trained extension personnel & 0.5812 & 0.49490 & $6^{\text {th }}$ \\
Availability of technology & 0.6813 & 0.46745 & $4^{\text {th }}$ \\
\hline
\end{tabular}

Source: Field Survey, 2012.

The Chi-square result in Table 7 shows that education $\left(x^{2}=18.057, p=0.000\right)$, marital status $\left(x^{2}=25.472, p=0.000\right)$, secondary occupation $\left(x^{2}=10.060, p=0.039\right)$, and types of crop grown $\left(X^{2}=4.321, p=0.028\right)$ had significant relationships with attitude towards NGEOs. It can then be said that: whether a farmer is positively or negatively disposed towards NGEOs is dependent on his level of education, since it is expected that a higher level of education should favour a positive attitude. Also, a married farmer, in order to live up to the marital obligations, may patronise the services of NGEOs so as to boost his farm production. Furthermore, whether a farmer would engage the services of NGEOs, which is administered at a cost, depends on the availability of finance and the crops a farmer grows which also relate to the scale of production, directly affects his attitude towards NGEOs.

PPMC also reveals significant relationship between years of formal education received by respondents, farming experience, number of hectares of land in use and attitude towards NGEOs. The implication is that farmers with less hectares will have favourable attitude because they will need more advice of NGEOs on how best to utilize the available land for maximum productivity. 
Table 7: Chi-square and PPMC relationship between personal characteristics, other variables and farmers' attitude towards NGEOs

\begin{tabular}{|c|c|c|c|c|c|c|}
\hline Variable & Df & $x^{2}-$ value & $p$-value & Variable & r-value & $p$-value \\
\hline Formal education & 3 & 18.057 & $0.000^{*}$ & $\begin{array}{ll}\text { Yrs of formal } \\
\text { educatn }\end{array}$ & 0.346 & $0.000^{*}$ \\
\hline Marital status & 4 & 25.472 & $0.000^{*}$ & $\begin{array}{l}\text { Farming } \\
\text { experience }\end{array}$ & 0.187 & $0.018^{*}$ \\
\hline $\begin{array}{l}\text { Secondary } \\
\text { occupation }\end{array}$ & 4 & 10.060 & $0.039^{*}$ & No of hectare & -0.171 & $0.030^{*}$ \\
\hline Types of crop grown & 1 & 4.321 & $0.028^{*}$ & Awareness & 6.884 & $0.009^{*}$ \\
\hline \multirow[t]{2}{*}{ Willingness to pay } & 1 & 9.525 & $0.002^{*}$ & $\begin{array}{l}\text { Source } \\
\text { information }\end{array}$ & 0.519 & $0.000^{*}$ \\
\hline & & & & Constraints & 0.428 & $0.000^{*}$ \\
\hline
\end{tabular}

${ }^{*}=$ significant

There was a significant relationship between respondents' willingness to pay and attitude of the farmers towards NGEOs $\left(x^{2}=9.525, p=0.002\right)$. The implication of this is that a farmer who is willing to offer a token in exchange for extension services definitely has a favourable attitude towards NGEOs and vice versa. There was a significant relationship $(r=6.884$, and $p=0.009)$ between awareness and respondents' attitude towards NGEOs. This infers that a farmer's attitude towards NGEOs services is a function of the awareness on the subject i.e. the more the respondents is well-informed about NGEOs services, the higher the probability that he will make use of the services in varying levels, which Akinbile and Odebode (2007) aligned with. In the same vein, source of information is significantly related to farmers attitude towards NGEOs $(r=0.519$ and $p=0.000)$. Thus, the credibility of a source of information, the frequency and consistency at which it relays information on NGEOs go a long way at influencing farmers' attitude towards the subject. A significant relationship also exist between constraints and attitude of respondents to NGEOs $(r=0.428$, $p=0.000$ ). It informs that farmers' use of NGEOs services will be limited when constraints abound.

\section{Conclusion and Recommendation}

The farmers were generally well aware of the NGEOs particularly FADU, through information sources like radio. They were also willing to offer money in exchange for extension services notwithstanding the constraints they faced, and thus exhibited favourable attitude towards NGEOs. Certain percentage of any assistance to be given to farmers should be committed on extension service hiring/sourcing in order to prepare farmers frame of mind towards the necessity of extension services. NGEOs should consider scale of operation and area of specialization of different farmers in charging. The services of NGEOs should be regulated by government to avoid exploitation of farmers. Synergies and collaboration between governmental and NGEOs become imperative for efficient and effective delivery of extension services particularly for agricultural transformation agenda to be achievable.

\section{References}

Adewoye, S.O, Fawole,O.O. and Omotosho, J.S. (2003). Concentrations of Selected Elements in some Fresh Water Fishes in Nigeria. Science Focus,Vol. 4, pp106-108. 
Agbebaku, O.M. (2004). Comparative Analysis in the Perception of Participants of Farm Practical Training Programme of the University of Ibadan and University of Agriculture, Abeokuta. An Unpublished BSc Project in the Department of Agricultural Extension and Rural Development, University of Ibadan, Nigeria.

Ajayi, M.T. (2003). Analysis of Mass Media Use for Agricultural Information by Farmers in

Egbeda Local Government of Oyo state, Nigeria. Journal of Extension Systems. Vol 19, No 22, pp45-55.

Akinbile, L.A. and Odebode, S.O. (2007). Determinants of Farmer's Use of Sustainable Soil Conservation Practices in Osun State, Nigeria. American-Eurasian Journal of Sustainable Agriculture, Vol, No 1, pp1-7.

Akinbile, L. A, Hussain, L. A. and Yekinni, O. T (2008): CDAs and CBOs Participation in Community-based Poverty Reduction Projects in Selected Communities in Ekiti State. Nigerian Journal of Rural Sociology, Vol. 8, No. 1, pp41-47.

Alex, G., Zijp W., Byerlee D. (2002): 'Rural Extension and Advisory Services: New directions'. Rural Strategy Background Paper, No. 9. Washington, D.C., AKIS Thematic Team, World Bank.

Angba, A.O. (2003): Effect of Rural Urban Migration of Youths on Agricultural Labour Supply in Umuahia North Local Government Area of Abia State. Journal of Agriculture and Social Research, Vol 3, No 2.

Ballantyne, P. and Bokre D. (2003): Report from the "Prepcom" (for CTA'sSixth Consultative Expert Meeting of its Observatory on ICTs). Wageningen the Netherlands p.34.

Kidd, A., Lamers J., Ficarelli, P., Hoffmann, V. (2000): Privatising agricultural extension: caveat emptor. Journal of Rural Studies, 16: 95-102.

Ogunlade, M.O., K.A. Oluyole and P.O. Aikpokpodion. (2009). An Evaluation of the Level of Fertilizer Utilization for Cocoa Production in Nigeria. Journal of Human Ecology. 25(3): 175-178.

Ogunsunmi, I.O. and Ewuola S.O. (2005): Adoption Behaviour of Farmers in South West Nigeria: The case of Soybean. Farmers Journal of Central European Agriculture, 6:421-432.

Rivera, W. (2001): Agriculture and Rural Extension Worldwide. Options for Institutional Reform in the Developing Countries. FAO: Rome.

Torimiro, D.O. and Oluborode, A.A. (2006): Explaining Socio Economic Correlates of Production Needs for Southwest Nigeria. Journal of Applied Science Research, Vol 5, pp248-255.

Van den ban, A.W., Hawkins, H.S. (1998): Agricultural Extension. 2nd Edition, Blackwell Science, pp5- 10. 